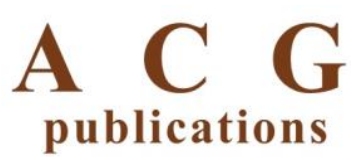

Rec. Nat. Prod. 13:6 (2019) 468-474

records of natural

products

\title{
Two New Lignans from Lycopodium japonicum Thunb.
}

\author{
Qin Ren ${ }^{1,2}$, Zhenxing Zou $\odot^{2}$, Yang Liu $\odot^{1}$, Xi Chen $\odot^{2}$, Kangping Xu $\odot^{2}$ \\ and Guishan Tan $1,2^{*}$ \\ ${ }^{I}$ Xiangya Hospital of Central South University, Changsha 410008, PR China \\ ${ }^{2}$ Xiangya School of Pharmaceutical Sciences, Central South University, Changsha 410013, PR China \\ (Received March 06, 2019; Revised April 02, 2019; Accepted April 03, 2019)
}

\begin{abstract}
Two new lignans, named lycojaponicumoside A (1) and B (2), together with four known compounds (3-6) were isolated from the $n$-BuOH extract of Lycopodium japonicum. Their structures were elucidated on the basis of extensive spectroscopic methods, especially various NMR techniques, HRESIMS and circular dichroism (CD). The absolute configuration of compound $\mathbf{1}$ was established by the calculation of electronic circular dichroism (ECD) curves. All of the compounds were evaluated for their cytotoxic activities against A549 and HepG2 human cancer cell lines, but those compounds did not exhibit cytotoxicity.
\end{abstract}

Keywords: Lycopodium japonicum; lignans; ECD calculation. (C) 2019 ACG Publications. All rights reserved.

\section{Introduction}

Lycopodium japonicum Thunb. ex Murray, a perennial herb belonging to the family Lycopodiacese, was widely distributed in Guangxi, Guizhou, Yunnan province of China. This plant was used as a traditional herbal medicine for the treatment of arthritis pain, contusion and myasthenia [1-2]. Previous phytochemical investigations of L. japonicum were mainly focused on the lycopodium alkaloids [3-6], and serratene-type triterpenoids [7-10], which were characteristic constituents of this genus. However, there has been little research on other types of compounds, such as flavonoids and lignans. In addition, the chemical constituents of this plant were mainly concentrated on the study of medium polarity and small polarity parts, while the research on high polarity part was rarely reported, which urged us to look for bioactive substances from the high polarity part of $75 \%$ aqueous ethanol extract of $L$. japonicum. Therefore, we carried out a systematic study on the $n$ - $\mathrm{BuOH}$ fraction, where two new lignans together with four known compounds were isolated. Herein, we reported the isolation, structural elucidation, and cytotoxicity against two human cancer cell lines (A549, HepG2) of all the isolated compounds from L. japonicum.

\section{Materials and Methods}

\subsection{General}

NMR spectra were recorded on a Bruker AV-500 MHz spectrometer (Bruker, Karlsruhe, Germany) with TMS as an internal standard. CD spectra were measured on a JASCO J-815 CD spectrometer (JASCO, Tokyo, Japan). HRESIMS were recorded on Agilent 1290 liquid

\footnotetext{
*Corresponding author: E-Mail: tgs395@csu.edu.cn 
chromatograph (Agilent Technologies, Ltd., Santa Clara, CA, USA) combined with Q-TOF mass spectrometry and Orbitrap Velos Pro ETD mass spectrometry (Thermo Fisher Scientific, Massachusetts, USA). Optical rotations were recorded on an INESA SGW-3 polarimeter. Semipreparative HPLC was performed on an Agilent 1260 series equipped with a VWD detector and YMC-pack ODS-A column $(10 \mu \mathrm{m}, 250 \times 10 \mathrm{~mm})$. Analytical HPLC was performed on an Agilent 1100 series equipped with a DAD detector and YMC-pack ODS-A column $(5 \mu \mathrm{m}, 250 \times 4.6 \mathrm{~mm})$. Macroporous resin HPD-100 (Cangzhou Bon Adsorber Technology Co. Ltd., Hebei, China) and Sephadex HW-40C (TOYOPEARL TOSOH, Tokyo, Japan) were used in the column chromatography (CC). All solvents used were analytical grade.

\subsection{Plant Material}

The air-dried whole herbs of L. japonicum Thunb. were collected from Guangxi Province, China in July 2015, and identified by Prof. Zhen-Ji Li (Xiamen University, Xiamen, China). A voucher specimen (SJC-2015-07) has been deposited at the Xiangya School of Pharmaceutical Sciences, Central South University, China.

\subsection{Extraction and Isolation}

The air-dried whole herbs of L. japonicum $(10.0 \mathrm{~kg})$ were extracted with $75 \% \mathrm{EtOH}$ three times under reflux then concentrated under reduced pressure to yield a residue, which was dispersed in $\mathrm{H}_{2} \mathrm{O}$ and extracted with petroleum ether, ethyl acetate, and $n-\mathrm{BuOH}$, successively.

The $n$ - $\mathrm{BuOH}$ fraction (100 g) was loaded on macroporous resin HPD-100 column chromatography and eluted with a gradient system of $\mathrm{H}_{2} \mathrm{O}, 30 \% \mathrm{EtOH}, 70 \% \mathrm{EtOH}, 95 \% \mathrm{EtOH}$ (Fr. AFr. D). Fr. B was performed on the Sephadex HW-40C with $\mathrm{MeOH} / \mathrm{H}_{2} \mathrm{O}$ to obtain forty fractions (Fr. B1-Fr. B40). Fr. B20-Fr. B22 were subjected to Sephadex HW-40C repeatedly and were subsequently purified by semi-preparative HPLC (YMC-pack ODS-A column, $10 \mu \mathrm{m}, 250 \times 10 \mathrm{~mm}, 3 \mathrm{ml} / \mathrm{min}$ ), eluted with $\mathrm{ACN} / \mathrm{H}_{2} \mathrm{O}(0 \sim 19 \mathrm{~min}, 15 \sim 34 \%)$ to yield compound $1\left(0.7 \mathrm{mg}, \mathrm{t}_{\mathrm{R}}=14.7 \mathrm{~min}\right)$. Fr. B10 was separated into ten fractions (Fr. B10.1-Fr. B10.10) by HW-40C, and Fr. B10.2- Fr. B10.3 were directly purified by semi-preparative HPLC (YMC-pack ODS-A column, $10 \mu \mathrm{m}, 250 \times 10 \mu \mathrm{mm}, 3 \mathrm{ml} / \mathrm{min}$ ), eluted with $\mathrm{ACN} / \mathrm{H}_{2} \mathrm{O}(0 \sim 30 \mathrm{~min}, 10 \sim 28 \%)$ to obtain $2\left(2.5 \mathrm{mg}, \mathrm{t}_{\mathrm{R}}=17.8 \mathrm{~min}\right)$. Fr. B10.5 was also purified by semi-preparative HPLC (YMC-pack ODS-A column, $10 \mu \mathrm{m}, 250 \times 10 \mathrm{~mm}, 3 \mathrm{ml} / \mathrm{min}$ ) with $\mathrm{ACN} / \mathrm{H}_{2} \mathrm{O}(0 \sim 15 \mathrm{~min}, 10 \sim 19 \% ; 15 \sim 30 \mathrm{~min}, 10 \sim 28 \%)$ to yield $\mathbf{3}\left(0.7 \mathrm{mg}, \mathrm{t}_{\mathrm{R}}=17.3 \mathrm{~min}\right)$ and $\mathbf{4}(2.7 \mathrm{mg}$, $\left.\mathrm{t}_{\mathrm{R}}=14.5 \mathrm{~min}\right)$. Compound $5(2.5 \mathrm{mg})$ and compound $\mathbf{6}(2.2 \mathrm{mg})$ were obtained from the Fr. B15- Fr. B16 by semi-preparative HPLC (YMC-pack ODS-A column, $10 \mu \mathrm{m}, 250 \times 10 \mathrm{~mm}, 3 \mathrm{ml} / \mathrm{min}$ ) eluted with $\mathrm{ACN} / \mathrm{H}_{2} \mathrm{O}(0 \sim 20 \mathrm{~min}, 10 \sim 30 \%$; 0 30 min, 15 45\%).

\subsection{Spectroscopic Data}

Lycojaponicumoside $A(\mathbf{1})$ : white amorphous powder; []$_{D}^{25}-14.1$ (c $\left.0.07, \mathrm{MeOH}\right)$; HRESIMS m/z: $491.1922[\mathrm{M}-\mathrm{H}]^{-}$(calcd for $\left.\mathrm{C}_{25} \mathrm{H}_{31} \mathrm{O}_{10}, 491.1917\right) ;{ }^{1} \mathrm{H}$ and ${ }^{13} \mathrm{C}$ NMR data see Table 1.

Lycojaponicumoside B (2): white amorphous powder; $\mathrm{CD}$ (c $0.31, \mathrm{MeOH}) \Delta \varepsilon_{242}+0.90, \Delta \varepsilon_{221}-$ 3.11; [ $]_{0}^{25}-19.1$ (c 0.10, MeOH); HRESIMS m/z: 549.1977 [M-H] $\left(\right.$ calcd for $\left.\mathrm{C}_{27} \mathrm{H}_{33} \mathrm{O}_{12}, 549.1972\right) ;{ }^{1} \mathrm{H}$ and ${ }^{13} \mathrm{C}$ NMR data see Table 1 .

\subsection{Computational Calculations}

Conformational analysis within an energy window of $3.0 \mathrm{kcal} / \mathrm{mol}$ was performed by using the OPLS3 molecular mechanics force field via the MacroModel ${ }^{1}$ panel of Maestro 10.2. The conformers (Figure S23) were further optimized with the software package Gaussian $09^{2}$ at the B3LYP/6-31G (2d,p) level. The 60 lowest electronic transitions were calculated using time-dependent density functional theory (TD-DFT) methods at the B3LYP/6-31G (2d,p) level. The rotational strengths of each electronic excitation were given using both dipole length and dipole velocity representations. ECD spectra of different conformers were simulated using a Gaussian function with a half-bandwidth 
of $0.3 \mathrm{eV}$. The overall theoretical ECD spectra were then obtained according to the Boltzmann weighting of each conformer. SpecDis software was used for the generation of ECD spectra.

\subsection{Cytotoxicity Assay}

A549, HepG2 cell lines were used to assess the cytotoxicity of all compounds. Tumor cells in logarithmic growth phase were collected, counted, resuspended in complete medium. Cell concentration was adjusted to the appropriate concentration, and $90 \mu \mathrm{L}$ of cell suspension was added to per well, then the cells were seeded into 96 -well plates at a density of $5 \times 10^{3}$ cells $/ \mathrm{mL}$ for $24 \mathrm{~h}$ at $37{ }^{\circ} \mathrm{C}$ with $5 \% \mathrm{CO}_{2}$. Cells were subsequently exposed to the sample dissolved in DMSO and diluted with the medium to the test concentrations, with the control (Staurosporine) and blank in each plate. After 48 hours of incubation, $100 \mu \mathrm{L}$ of CCK8 assay solution was added to each well. Absorbance was detected by a microplate spectrophotometer at $450 \mathrm{~nm}$ after $1.5 \mathrm{~h}$.

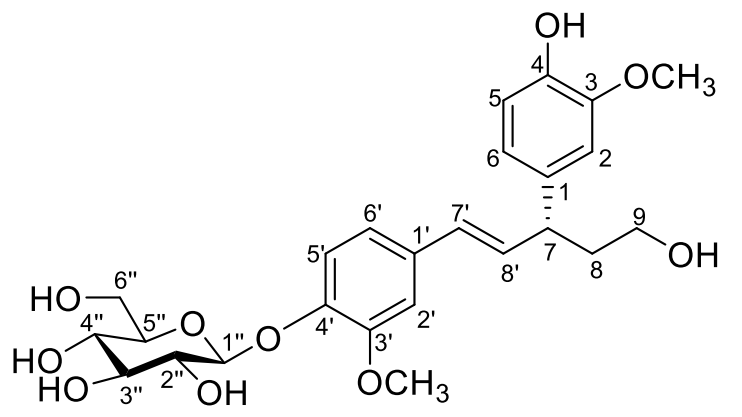

1<smiles>[R]CC1c2cc(CCCO)cc(OC)c2OC1c1ccc([R2])c([R3])c1</smiles>

$3 \mathrm{R}_{1}=\mathrm{OH}, \mathrm{R}_{2}=\mathrm{OH}, \mathrm{R}_{3}=\mathrm{OCH}_{3}$

$4 \mathrm{R}_{1}=\mathrm{OH}, \mathrm{R}_{2}=\mathrm{OGIC}, \mathrm{R}_{3}=\mathrm{OCH}_{3}$

$5 \mathrm{R}_{1}=\mathrm{OGIC}, \mathrm{R}_{2}=\mathrm{OCH}_{3}, \mathrm{R}_{3}=\mathrm{OH}$<smiles>CC(C)(O)OCC(O)C(O)CO</smiles>

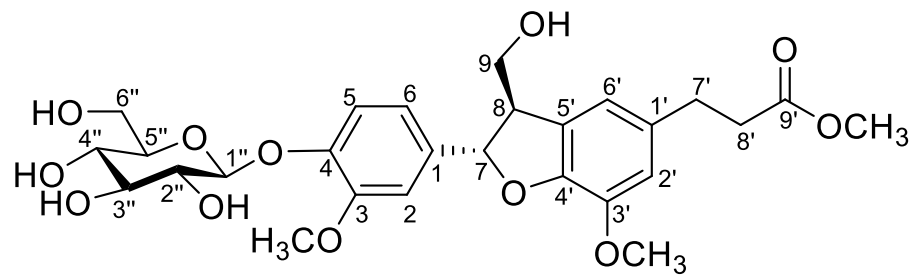

2<smiles>COc1cc(C2OCC3C(c4ccc(OC5CCCCC5)c(OC)c4)OCC23)ccc1O</smiles>

6

Figure 1. Structures of compounds 1-6

\section{Results and Discussion}

\subsection{Structure Elucidation}

Compound 1, obtained as white amorphous powder, had a molecular formula of $\mathrm{C}_{25} \mathrm{H}_{32} \mathrm{O}_{10}$ on the basis of an HRESIMS at $\mathrm{m} / z$ 491.1922 [M-H] ${ }^{-}$(calcd for $\mathrm{C}_{25} \mathrm{H}_{31} \mathrm{O}_{10}, 491.1917$ ), which implied ten degrees of unsaturation. The ${ }^{1} \mathrm{H}$ NMR spectrum (Table 1) revealed six aromatic protons, including two sets of 1,3,4-trisubstituted aromatic rings at $\delta_{\mathrm{H}} 6.77(1 \mathrm{H}, \mathrm{d}, J=2.0 \mathrm{~Hz}, \mathrm{H}-2), 6.70(1 \mathrm{H}, \mathrm{d}, J=8.0 \mathrm{~Hz}$, H-5), $6.64(1 \mathrm{H}, \mathrm{dd}, J=8.0,2.0 \mathrm{~Hz}, \mathrm{H}-6)$ and $7.01(1 \mathrm{H}, \mathrm{d}, J=1.5 \mathrm{~Hz}, \mathrm{H}-2), 7.09(1 \mathrm{H}, \mathrm{d}, J=8.5 \mathrm{~Hz}$, 
H-5'), $6.89\left(1 \mathrm{H}, \mathrm{dd}, J=8.5 \mathrm{~Hz}, 1.5 \mathrm{~Hz}, \mathrm{H}-6^{\prime}\right)$, two trans-olefinic protons at $\delta_{\mathrm{H}} 6.27(1 \mathrm{H}, \mathrm{d}, J=15.8$ $\left.\mathrm{Hz}, \mathrm{H}^{-} 7^{\prime}\right)$ and $6.06\left(1 \mathrm{H}, \mathrm{dd}, J=15.8,8.3 \mathrm{~Hz}, \mathrm{H}-8^{\prime}\right)$, one methine signal at $\delta_{\mathrm{H}} 2.58(1 \mathrm{H}, \mathrm{m}, \mathrm{H}-7)$, one methylene signal at $\delta_{\mathrm{H}} 2.60(1 \mathrm{H}, \mathrm{m}, \mathrm{H}-8 \mathrm{a}) / 2.83(1 \mathrm{H}, \mathrm{m}, \mathrm{H}-8 \mathrm{~b})$, one oxygenated methylene group at $\delta_{\mathrm{H}}$ $3.60(2 \mathrm{H}, \mathrm{t}, J=5.5 \mathrm{~Hz}, \mathrm{H}-9)$, and two methoxyl groups at $\delta_{\mathrm{H}} 3.79(3 \mathrm{H}, \mathrm{s})$ and $3.88(3 \mathrm{H}, \mathrm{s})$, additionally, a glucopyranosyl anomeric proton at $\delta_{\mathrm{H}} 4.88$ was overlapped by $\mathrm{H}_{2} \mathrm{O}$ peak, which occurred when measured in DMSO- $d_{6}$ (Figure S4). Combining with DEPT spectrum, the ${ }^{13} \mathrm{C}$ NMR data (Table 1) totally showed 25 carbon signals (one overlapping carbon signal) including two methoxyls, two methylenes, nine methines, six quaternary carbons, and the remaining six carbon signals could be attributed to a glucopyranosyl unit. The ${ }^{1} \mathrm{H}^{-1} \mathrm{H}$ COSY correlations of $\mathrm{H} 77^{1} / \mathrm{H} 8^{1} / \mathrm{H} 7 / \mathrm{H} 8 \mathrm{~b}$ and $\mathrm{H} 8 \mathrm{a} / \mathrm{H} 9$ proved the presence of $\mathrm{CH}\left(7^{\prime}\right)=\mathrm{CH}\left(8^{\prime}\right)-\mathrm{CH}(7)-\mathrm{CH}_{2}(8)-\mathrm{CH}_{2}(9)$ unit (Figure S1). In the $\mathrm{HMBC}$ spectrum, the correlations from $\delta_{\mathrm{H}} 2.58(\mathrm{H}-7) / 2.83(\mathrm{H}-8 \mathrm{~b})$ to $\delta_{\mathrm{C}} 131.6(\mathrm{C}-1)$ could be observed, which suggested that $\mathrm{C}-7$ was connected to $\mathrm{C}-1$; while the $\mathrm{HMBC}$ correlations from $\delta_{\mathrm{H}} 6.27\left(\mathrm{H}-7^{\prime}\right)$ to $\delta_{\mathrm{C}} 133.1\left(\mathrm{C}-1^{\prime}\right), 109.8\left(\mathrm{C}-2^{\prime}\right), 118.9\left(\mathrm{C}-6^{\prime}\right)$ and from $\delta_{\mathrm{H}} 6.06\left(\mathrm{H}^{\prime}-8^{\prime}\right)$ to $\delta_{\mathrm{C}} 133.1\left(\mathrm{C}-1^{\prime}\right)$ indicated that C-7' was connected to $\mathrm{C}-1$ '. The position of the two methoxyl groups was confirmed by the HMBC correlation from $\delta_{\mathrm{H}} 3.79(3 \mathrm{H}, \mathrm{s})$ to $\delta_{\mathrm{C}} 147.2(\mathrm{C}-3)$ and from $\delta_{\mathrm{H}} 3.88(3 \mathrm{H}, \mathrm{s})$ to $\delta_{\mathrm{C}} 149.5\left(\mathrm{C}-3^{\prime}\right)$. Furthermore, the large coupling constant $(J=7.5 \mathrm{~Hz})$ determined the $\beta$-configuration of the glucopyranosyl group (Figure S4), which was attached to C-4' based on the HMBC correlation between anomeric proton $\delta_{\mathrm{H}} 4.88$ (H-1") and $\delta_{\mathrm{C}} 145.9$ (C-4'). The above evidences suggested 1 belonged to the $\mathrm{C}_{6}-\mathrm{C}_{2}-\mathrm{C}_{3}-\mathrm{C}_{6}$ skeleton class, similar to metasequirin $\mathrm{D}$ [11].

The absolute configuration of $\mathbf{1}$ was determined by comparing its experimental with calculated ECD spectra. In the 200-400 $\mathrm{nm}$ region, compared with the calculated ECD spectra of $7 R$, the theoretically calculated ECD spectra of $7 S$ was in better agreement with the experimental ECD spectra of 1 (Figure S22). This allowed the assignment of the $7 S$ configuration for compound $\mathbf{1}$. Based on the obtained evidences, the structure of $\mathbf{1}$ was identified as shown in Figure 1, and named as lycojaponicumoside A.

Compound 2 was obtained as white amorphous powder. Its molecular formula was determined as $\mathrm{C}_{27} \mathrm{H}_{34} \mathrm{O}_{12}$ by HRESIMS at $m / z 549.1977[\mathrm{M}-\mathrm{H}]^{-}$(calcd for $\mathrm{C}_{27} \mathrm{H}_{33} \mathrm{O}_{12}$ 549.1972), indicating eleven degrees of unsaturation. The ${ }^{1} \mathrm{H}$ NMR spectrum (Table 1) of 2 showed the presence of a set of 1,3,4trisubstituted aromatic ring at $\delta_{\mathrm{H}} 7.04(1 \mathrm{H}$, br. s, H-2), $7.16(1 \mathrm{H}, \mathrm{d}, J=8.0 \mathrm{~Hz}, \mathrm{H}-5), 6.94(1 \mathrm{H}, \mathrm{br}$. d, $J$ $=8.0 \mathrm{~Hz}, \mathrm{H}-6)$, a set of 1,3,4,5-tetrasubstituted aromatic ring at $\delta_{\mathrm{H}} 6.76(1 \mathrm{H}$, br. s, H-2'), $6.74(1 \mathrm{H}, \mathrm{br}$. s, H-6'), one oxygenated methine group at $\delta_{\mathrm{H}} 5.58(1 \mathrm{H}, \mathrm{d}, J=6.0 \mathrm{~Hz}, \mathrm{H}-7)$, one methine group at $\delta_{\mathrm{H}}$ $3.46(1 \mathrm{H}, \mathrm{m}, \mathrm{H}-8)$, one hydroxymethyl group at $\delta_{\mathrm{H}} 3.76(1 \mathrm{H}, \mathrm{m}, \mathrm{H}-9 \mathrm{a}) / 3.85(\mathrm{H}-9 \mathrm{~b})$, two methylenes groups at $\delta_{\mathrm{H}} 2.87\left(2 \mathrm{H}, \mathrm{t}, J=7.5 \mathrm{~Hz}, \mathrm{H}-7^{\prime}\right), 2.63\left(2 \mathrm{H}, \mathrm{t}, J=7.5 \mathrm{~Hz}, \mathrm{H}-8^{\prime}\right)$, and three methoxyl groups at $\delta_{\mathrm{H}} 3.85(3 \mathrm{H}, \mathrm{s}), 3.88(3 \mathrm{H}, \mathrm{s}), 3.67(3 \mathrm{H}, \mathrm{s})$, in addition, a glucopyranosyl anomeric proton at $\delta_{\mathrm{H}} 4.91$ was affected by $\mathrm{H}_{2} \mathrm{O}$ peak, which occurred when measured in DMSO- $d_{6}$ (Figure S26). Combining with DEPT spectrum, the ${ }^{13} \mathrm{C}$ NMR spectrum (Table 1) totally exhibited 27 carbon signals including three methoxyls, three methylenes, seven methines, eight quaternary carbons, and six carbon signals belonging to a glucopyranosyl unit. The ${ }^{1} \mathrm{H}-{ }^{1} \mathrm{H}$ COSY correlations of $\mathrm{H}-7 / \mathrm{H}-8 / \mathrm{H}-9 \mathrm{a}, \mathrm{H}-5 / \mathrm{H}-6$ and $\mathrm{H}-$ $7^{\prime} / \mathrm{H}-8^{\prime}$, together with the HMBC correlations (Figure S2) from $\delta_{\mathrm{H}} 5.58(\mathrm{H}-7)$ to $\delta_{\mathrm{C}} 137.0(\mathrm{C}-1), 109.8$ $(\mathrm{C}-2), 118.0(\mathrm{C}-6), 54.2(\mathrm{C}-8), 63.6(\mathrm{C}-9)$ and from $\delta_{\mathrm{H}} 3.46(\mathrm{H}-8)$ to $\delta_{\mathrm{C}} 137.0(\mathrm{C}-1), 63.6(\mathrm{C}-9), 146.2$ (C-4'), 128.4 (C-5') suggested that 2 was a dihydrobenzofuran neolignan [12-13]. In particular, the NMR data of 2 were similar to those of $(7 S, 8 R)$-urolignoside except for the absence of $-\mathrm{CH}_{2}-\mathrm{CH}_{2}-$ $\mathrm{CH}_{2} \mathrm{OH}$ and presence of $-\mathrm{CH}_{2}-\mathrm{CH}_{2} \mathrm{COOCH}_{3}$ [14], the $\mathrm{HMBC}$ correlations between $\delta_{\mathrm{C}} 173.9\left(\mathrm{C}-9^{\prime}\right)$ and $\delta_{\mathrm{H}} 2.87\left(\mathrm{H}^{-} 7^{\prime}\right) / 2.63\left(\mathrm{H}-8^{\prime}\right) / 3.67(3 \mathrm{H}, \mathrm{s})$ established the position of 9'- $\mathrm{OCH}_{3}$. Furthermore, the HMBC correlations from $\delta_{\mathrm{H}} 3.85(3 \mathrm{H}, \mathrm{s})$ to $\delta_{\mathrm{C}} 149.6(\mathrm{C}-3)$ and from $\delta_{\mathrm{H}} 3.88(3 \mathrm{H}, \mathrm{s})$ to $\delta_{\mathrm{C}} 144.0\left(\mathrm{C}-3^{\prime}\right)$ confirmed that the two methoxyl groups were connected to C-3 and C-3', respectively. The large coupling constant $(J=7.0 \mathrm{~Hz})$ indicated $\beta$-configuration of the glucose moiety (Figure S26), which was connected at $\mathrm{C}-4$ according to the HMBC correlation between anomeric proton $\delta_{\mathrm{H}} 4.91(\mathrm{H}-1 ")$ and $\delta_{\mathrm{C}} 146.5(\mathrm{C}-4)$.

The relative configuration of $\mathrm{H}-7$ and $\mathrm{H}-8$ was trans based on the $J_{\mathrm{H} 7, \mathrm{H} 8}(6.0 \mathrm{~Hz})$ coupling constant [15-16], which was determined by the NOE correlations $(\mathrm{H}-7 / \mathrm{H}-9, \mathrm{H}-8 / \mathrm{H}-2)$. Previous literature revealed that the absolute configurations at $\mathrm{C}-7$ and $\mathrm{C}-8$ of dihydrobenzofuran skeleton could be clearly distinguished from the 240-220 nm region of CD curves [16]. Therefore the absolute configuration of 2 was assigned $7 S, 8 R$ according to a positive Cotton effect at $242 \mathrm{~nm}$ and a negative 
one at $221 \mathrm{~nm}$ in the CD spectra (Figure S45). The structure of 2 was identified as shown in Figure 1 and named as lycojaponicumoside $\mathrm{B}$.

Additionally, the known compounds were identified as dihydrodehydrodiconiferyl alcohol (3) [17], urolignoside (4) [14], 3-( $\beta$-D-glucopyranosyloxymethyl)-2-(4-hydroxy-3-methoxyphenyl)-5-(3hydroxypropyl)-7-methoxydihydrobenzofuran (5) [18], and pinoresinol-4- $O$-glucoside (6) [19], by comparing their physical and spectroscopic data with those reported.

Table 1. ${ }^{1} \mathrm{H}$ NMR $(500 \mathrm{MHz})$ and ${ }^{13} \mathrm{C}$ NMR $(125 \mathrm{MHz})$ data of compounds 1-2 in $\mathrm{CD}_{3} \mathrm{OD}$

\begin{tabular}{|c|c|c|c|c|c|}
\hline \multicolumn{3}{|c|}{1} & \multicolumn{3}{|c|}{2} \\
\hline Position & $\delta_{\mathrm{H}}($ mult., $J$ in $\mathrm{Hz})$ & $\delta_{\mathrm{C}}$ & Position & $\delta_{\mathrm{H}}($ mult., $J$ in $\mathrm{Hz})$ & $\delta_{\mathrm{C}}$ \\
\hline 1 & & 131.6 & 1 & & 137.0 \\
\hline 2 & $6.77(1 \mathrm{H}, \mathrm{d}, 2.0)$ & 112.9 & 2 & $7.04(1 \mathrm{H}$, br. s $)$ & 109.8 \\
\hline 3 & & 147.2 & 3 & & 149.6 \\
\hline 4 & & 144.6 & 4 & & 146.5 \\
\hline 5 & $6.70(1 \mathrm{H}, \mathrm{d}, 8.0)$ & 114.5 & 5 & $7.16(1 \mathrm{H}, \mathrm{d}, 8.0)$ & 116.7 \\
\hline 6 & $6.64(1 \mathrm{H}, \mathrm{dd}, 8.0,2.0)$ & 121.5 & 6 & $6.94(1 \mathrm{H}$, br. d, 8.0$)$ & 118.0 \\
\hline 7 & $2.58(1 \mathrm{H}, \mathrm{m})$ & $47.8\left(\mathrm{ovl}^{\mathrm{a}}\right)$ & 7 & $5.58(1 \mathrm{H}, \mathrm{d}, 6.0)$ & 87.1 \\
\hline $8 \mathrm{a}$ & $2.60(1 \mathrm{H}, \mathrm{m})$ & 37.2 & 8 & $3.46(1 \mathrm{H}, \mathrm{m})$ & 54.2 \\
\hline $8 b$ & $2.83(1 \mathrm{H}, \mathrm{m})$ & & & & \\
\hline \multirow[t]{2}{*}{9} & $3.60(2 \mathrm{H}, \mathrm{t}, 5.5)$ & 64.6 & $9 \mathrm{a}$ & $3.76(1 \mathrm{H}, \mathrm{m})$ & 63.6 \\
\hline & & & $9 \mathrm{~b}$ & $3.85\left(\mathrm{ovl}^{\mathrm{a}}\right)$ & \\
\hline $3-\mathrm{OCH}_{3}$ & $3.79(3 \mathrm{H}, \mathrm{s})$ & 55.0 & $3-\mathrm{OCH}_{3}$ & $3.85(3 \mathrm{H}, \mathrm{s})$ & 55.4 \\
\hline $1^{\prime}$ & & 133.1 & $1^{\prime}$ & & 134.2 \\
\hline $2^{\prime}$ & $7.01(1 \mathrm{H}, \mathrm{d}, 1.5)$ & 109.8 & $2^{\prime}$ & $6.76(1 \mathrm{H}$, br. s $)$ & 112.7 \\
\hline $3^{\prime}$ & & 149.5 & $3^{\prime}$ & & 144.0 \\
\hline $4^{\prime}$ & & 145.9 & $4^{\prime}$ & & 146.2 \\
\hline $5^{\prime}$ & $7.09(1 \mathrm{H}, \mathrm{d}, 8.5)$ & 116.6 & $5^{\prime}$ & & 128.4 \\
\hline $6^{\prime}$ & $6.89(1 \mathrm{H}, \mathrm{dd}, 8.5,1.5)$ & 118.9 & $6^{\prime}$ & $6.74(1 \mathrm{H}$, br. s $)$ & 116.5 \\
\hline $7^{\prime}$ & $6.27(1 \mathrm{H}, \mathrm{d}, 15.8)$ & 130.2 & $7^{\prime}$ & $2.87(2 \mathrm{H}, \mathrm{t}, 7.5)$ & 30.4 \\
\hline \multirow[t]{2}{*}{$8^{\prime}$} & $6.06(1 \mathrm{H}, \mathrm{dd}, 15.8,8.3)$ & 130.6 & $8^{\prime}$ & $2.63(2 \mathrm{H}, \mathrm{t}, 7.5)$ & 35.7 \\
\hline & & & $9^{\prime}$ & & 173.9 \\
\hline \multirow[t]{2}{*}{$3^{\prime}-\mathrm{OCH}_{3}$} & $3.88(3 \mathrm{H}, \mathrm{s})$ & 55.3 & $3^{\prime}-\mathrm{OCH}_{3}$ & $3.88(3 \mathrm{H}, \mathrm{s})$ & 55.3 \\
\hline & & & 9'-OCH 3 & $3.67(3 \mathrm{H}, \mathrm{s})$ & 50.6 \\
\hline Glc & & & Glc & & \\
\hline $1 "$ & $4.88\left(\mathrm{ovl}^{\mathrm{a}}\right)$ & 101.5 & $1 "$ & $4.91\left(\mathrm{ovl}^{\mathrm{a}}\right)$ & 101.4 \\
\hline $2 "$ & $3.50(1 \mathrm{H}, \mathrm{m})$ & 73.5 & $2 "$ & $3.50(1 \mathrm{H}, \mathrm{m})$ & 73.5 \\
\hline 3" & $3.41(1 \mathrm{H}, \mathrm{m})$ & 76.8 & 3" & $3.40(1 \mathrm{H}, \mathrm{m})$ & 76.8 \\
\hline 4" & $3.40(1 \mathrm{H}, \mathrm{m})$ & 70.0 & 4" & $3.41(1 \mathrm{H}, \mathrm{m})$ & 70.0 \\
\hline $5 "$ & $3.47(1 \mathrm{H}, \mathrm{m})$ & 76.5 & $5 "$ & $3.48(1 \mathrm{H}, \mathrm{m})$ & 76.5 \\
\hline 6"a & $3.72(1 \mathrm{H}, \mathrm{m})$ & 61.1 & $6 \mathrm{aa}$ & $3.70(1 \mathrm{H}, \mathrm{m})$ & 61.1 \\
\hline 6"b & $3.88\left(\right.$ ovl $\left.^{\mathrm{a}}\right)$ & & $6 " \mathrm{~b}$ & $3.86\left(\mathrm{ovl}^{\mathrm{a}}\right)$ & \\
\hline
\end{tabular}

a. Overlapping signals

\subsection{Cytotoxicity}

Compounds 1-6 were evaluated for their cytotoxic activities against two human cancer cell lines (A549, HepG2). However, all the compounds showed no cytotoxicity.

\section{Acknowledgments}

This work was financially supported by the Key Project of Changsha Science and Technology Plan (No. kq1801072). The authors gratefully acknowledge all members of High Resolution Mass Spectrometry Laboratory of Advanced Research Center and Modern Analysis and Testing Centre in Central South University for the HRESIMS and NMR measurement. 


\section{Supporting Information}

Supporting information accompanies this paper on http://www.acgpubs.org/journal/records-of$\underline{\text { natural-products }}$

\section{ORCID}

Qin Ren: 0000-0002-2694-4400

Zhenxing Zou: 0000-0003-2711-7391

Yang Liu: 0000-0001-9209-2392

Xi Chen: 0000-0003-4837-1874

Kangping Xu: 0000-0002-0010-5430

Guishan Tan: 0000-0001-8041-6185

\section{References}

[1] Chinese Pharmacopoeia Commission (2010). Pharmacopoeia of the People's Republic of China, part I, China Medical Science Press, Beijing, China.

[2] X. C. Zhang and L. B. Zhang (2004). Flora of China, vol. 6, Science Press, Beijing, China.

[3] J. He, X. D. Wu, F. Liu, Y. C. Liu, L. Y. Peng, Y. Zhao, X. Cheng, H. R. Luo and Q. S. Zhao (2014). Lycopodine-type alkaloids from Lycopodium japonicum, Nat. Prod. Bioprospect. 4, 213-219.

[4] X. J. Wang, L. Li, Y. K. Si, S. S. Yu, S. G. Ma, X. Q. Bao, D. Zhang, J. Qu, Y. B Liu and Y. Li (2013). Nine new lycopodine-type alkaloids from Lycopodium japonicum Thunb., Tetrahedron 69, 6234-6240.

[5] X. J. Wang, G. J. Zhang, P. Y. Zhuang, Y. Zhang, S. S. Yu, X. Q. Bao, D. Zhang, Y. H. Yuan, N. H. Chen, S. G. Ma, J. Qu and Y. Li (2012). Lycojaponicumins A-C, three alkaloids with an unprecedented skeleton from Lycopodium japonicum, Org. Lett. 14, 2614-2617.

[6] Q. Yang, Y. Q. Zhu, W. Peng, R. Zhan and Y. G. Chen (2016). A New lycopodine-type alkaloid from Lycopodium japonicum, Nat. Prod. Res. 30, 2220-2224.

[7] X. L. Li, Y. Zhao, X. Cheng, L. Tu, L. Y. Peng, G. Xu and Q. S. Zhao (2006). Japonicumins A-D: four new compounds from Lycopodium japonicum, Helv. Chim. Acta. 89, 1467-1473.

[8] Z. H. Sun, W. Li, G. H. Tang and S. Yin (2017). A new serratene triterpenoid from Lycopodium japonicum, J. Asian. Nat. Prod. Res. 19, 299-303.

[9] X. J. Wang, D. Q. Yu and S. S. Yu (2014). Two new triterpenoids from Lycopodium japonicum Thunb., Chin. J. Chem. 32, 1007-1010.

[10] Y. Zhang, P. Yi, Y. Chen, Z. N. Mei, X. Hu and G. Z. Yang (2014). Lycojaponicuminol A-F: cytotoxic serratene triterpenoids from Lycopodium japonicum, Fitoterapia 96, 95-102.

[11] L. B. Dong, J. He, Y. Y. Wang, X. D. Wu, X. Deng, Z. H. Pan, G. Xu, L. Y. Peng, Y. Zhao, Y. Li, X. Gong and Q. S. Zhao (2011). Terpenoids and norlignans from Metasequoia glyptostroboides, J. Nat. Prod. 74, 234-239.

[12] X. Li, J. G. Luo, X. B. Wang, J. Luo, J. S. Wang and L. Y. Kong (2012). Phenolics from Leontopodium leontopodioides inhibiting nitric oxide production, Fitoterapia 83, 883-887.

[13] Q. B. Liu, X. X. Huang, X. J. Yan, M. Bai, L. H. Yu, C. Hu, T. Zhu, L. Z. Li and S. J. Song (2014). Neolignans from the seeds of Prunus tomentosa (Rosaceae) and their chemotaxonomic interest, Biochem. Syst. Ecol. 55, 236-240.

[14] H. X. Kuang, Y. G. Xia, B. Y. Yang, Q. H. Wang and S. W. Lü (2009). Lignan constituents from Chloranthus japonicus Sieb, Arch. Pharm. Res. 32, 329-334.

[15] G. Lemiere, M. Gao, A. D. Groot, R. Dommisse, J. Lepoivre, L. Pieters and V. Buss (1995). 3',4-Di-Omethylcedrusin: synthesis, resolution and absolute configuration, J. Chem. Soc., Perkin. Trans. 26, 1775-1779.

[16] N. Matsuda, H. Sato, Y. Yaoita and M. Kikuchi (1996). Isolation and absolute structures of the neolignan glycosides with the enantiometric aglycones from the leaves of Viburnum awabuki K. Koch, Chem. Pharm. Bull. 44, 1122-1123.

[17] C. H. Park, K. H. Kim, I. K. Lee, S. Y. Lee, S. U. Choi, J. H. Lee and K. R. Lee (2011). Phenolic constituents of Acorus gramineus, Arch. Pharm. Res. 34, 1289-1296. 
[18] H. Kikuzaki, S. I. Kayano, N. Fukutsuka, A. Aoki, K. Kasamatsu, Y. Yamasaki, T. Mitani and N. Nakatani (2004). Abscisic acid related compounds and lignans in Prunes (Prunus domestica L.) and their oxygen radical absorbance capacity (ORAC), J. Agric. Food. Chem. 52, 344-349.

[19] D. K. Kim, J. P. Lim, J. W. Kim, H. W. Park and J. S. Eun (2005). Antitumor and antiinflammatory constituents from celtis sinensis, Arch. Pharm. Res. 28, 39-43.

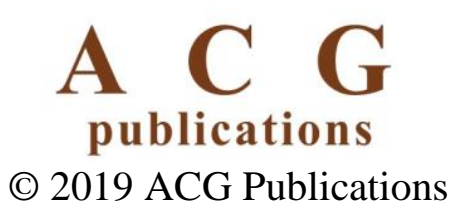

